\title{
DAMPAK WISATA PANTAI NAMBO TERHADAP PEREKONOMIAN MASYARAKAT DI KELURAHAN NAMBO KECAMATAN ABELI KOTA KENDARI
}

\author{
${ }^{1}$ Iis Yuliarsih
}

\author{
${ }^{1}$ Alumni Pendidikan Geografi Universitas Halu Oleo
}

\begin{abstract}
Dampak pengembangan wisata pantai nambo terhadap perekonomian masyarakat di kelurahan nambo kecamatan abeli kota kendari. Penelitian ini bertujuan untuk mengetahui dampak pengembangan wisata bahari pantai nambo terhadap perkonomian masyarakat di kelurahan nambo kecamatan abeli kota kendari. Metode pengumpulan data dimulai dari observasi penelitian dan wawancara langsung pada sasaran penelitian dan dokumentasi. Selanjutnya hasil penelitian dianalisis melalui metode deskriptif kualitatif. Hasil penelitian di peroleh bahwa sebelum pengembangan objek wisata aktifitas ekonomi masyarakat pada umumnya sebagai petani dan nelayan namun sesudah pengembangan objek wisata melelui penyediaan sarana dan prasarana kemudian hubungan antara masyarakat dengan wisatawan yang akrab sehingga meningkatkan jumlah pengunjung aktivitas ekonomi masyarakat bertambah yakni sebagai pedagang(kios/kantin dan penyedia fasilitas banana boact ban pelampung, sewa tikar, kazebo, ruang bilas dan penginapan meningkatkan pendapatan masyarakat secara segnifikan. Dengan demikian pengembangan objek wisata memberikan dampak positif bagi peningkatan perekonomian masyarakat di kelurahan nambo. Hasil tersebut menyimpulkan bahwa objek wisata pantai nambo memberikan dampak yang lebih baik antara lain menambah aktivitas ekonomi dan pendapatan masyarakat kelurahan nambo kecamatan abeli kota kendari.
\end{abstract}

Kata kunci: Dampak Objek Wisata Pantai, Aktivitas Dan Pendapatan Masyarakat. 


\title{
IMPACT OF NAMBO BEACH TOURISM DEVELOPMENT ON COMMUNITY ECONOMY IN NAMBO VILLAGE ABELI DISTRICT KENDARI CITY
}

\author{
${ }^{1}$ Iis Yuliarsih
}

\author{
${ }^{1}$ Alumni Of Halu Oleo University Geography Education
}

\begin{abstract}
Impact of Nambo Beach Tourism Development on Community Economy in Nambo Village Abeli District Kendari City. This study aims to determine the impact of the development of Nambo coastal marine tourism to the economy of the community in Nambo Village, Abeli Subdistrict, Kendari City. Data collection method starts from research observations and interviews directly with the research and documentation targets. Furthermore, the results of the study were analyzed through qualitative descriptive methods. The results obtained that before the development of tourism economic activities of the community in general as farmers and fishermen, but after the development of tourism objects through the provision of facilities and infrastructure, then the relationship between the community and tourists who are familiar so as to increase the number of visitors, the economic activity of the community increases as traders (kiosks / canteen) and providers of facilities such as banana boats, buoy tires, rental mats, gazebos, rinse rooms and lodgings, significantly increase people's income. Thus the development of tourism objects has a positive impact on improving the economy of the community in Nambo Village. These results conclude that Nambo beach tourism has a better impact, among others, can increase economic activity and income of the people in Nambo Village, Abeli District, Kendari City.
\end{abstract}

\section{Keywords: Impact of Beach Tourism, Activities and Community Income}

\section{PENDAHULUAN}

Sistem perencanaan pembangunan yang selama ini cenderung seragam, mulai berubah dan cenderung bervariasi tergantung potensi dan permasalahan pokok yang dialami oleh daerah yang bersangkutan (Sjarizal, 2014:14).

Salah satu sektor potensi yang dimiliki suatu daerah yaitu pariwisata. Berdasarkan Undang-Undang nomor 12 tahun 2005 tentang pariwisata yang dikutip dalam Rahman (2006), tujuan pengembangan pariwisata tidak lain adalah untuk menciptakan multipler effect, diantaranya adalah: (1) memperluas dan memeratakan kesempatan berusaha dan lapangan kerja; (2) meningkatkan pendapatan nasional dalam rangka meningkatkan kesejahteraan dan kemakmuran rakyat; (3) mendorong pendayagunaan produksi nasional.
Pariwisata sebagai industri yang menjual lingkungan hidup fisik dan social budaya sangat menuntut adanya lingkungan baik fisik, sosial, budaya, politik senantiasa berada dalam kondisi bersih dan terjamin keamanannya. Dalam bidang pariwisata ada tiga faktor yang menentukan keberhasilan pengelolaan ingkungan wisata yaitu: 1) Masyarakat di lokasi wisata 2)Pemerintah/swasta, 3) Pengunjung/wisatawan. Dengan kata lain, pembangunan pariwisata pada suatu daerah tujuan wisata selalu akan diperhitungkan dengan keuntungan dan manfaat bagi rakyat banyak (Departemen P\&K Yogyakarta. 1999).

Namun kita juga menyadari bahwa banyak permasalahan yang kita hadapi dalam menggerakkan potensi kemasyarakatan melalui pemberdayaan dan partisipasi masyarakat sekelurahan di sekitar kawasan pengembangan. Pengembangan kawasan pariwisata pantai 
dan laut merupakan kegiatan wisata yang memiliki aktifitas yang berkaitan dengan pantai dan laut, baik disepanjang pantai, di atas permukaan laut maupun kegiatan yang di lakukan dibawah permukaan laut. Pariwisata pantai dan laut sebagai salah satu aspek pemanfaatan dalam pengelolaan sunber daya alam mempunyai peluang yang amat baik untuk dikembangkan. Pantai Nambo merupakan daerah wisata pantai yang dijadikan daerah sektor ekonomi kerakyatan. Objek wisata ini mampu memberikan peranan ekonomi bagi masyarakat sekitar.

Pantai Nambo sebagai obyek wisata andalan Pemerintah Kota Kendari, Sulawesi Tenggara (SULTRA) mudah dijangkau, baik oleh wisatawan lokal maupun dari luar daerah. Pantai ini diminati banyak pengunjung karena letaknya yang relatif dekat. Pantai Nambo memiliki pasir putih yang landai suasana yang tenang, udara yang sejuk dan panorama yang menakjubkan sehingga tempat ini selalu merupakan pilihan masyarakat Kota Kendari untuk melepas kejenuhan dan rutinitas sehari-hari.

Pada wisata pantai Nambo ini dinilai masyarakatnya 1) belum menerapkan peraturan pemerintah setempat secara maksimal yang mendukung arahan keikutsertaan masyarakat dalam pemanfaaaatan sumber daya alam guna mendukung pariwisata alam, 2) keterampilan masyarakat lokal dalam mengelola manfaat ekonomis dari peluang-peluang untuk menunjang pariwisata alam masih rendah 3) permodalan dan infrastruktur ekonomi masyarakat lokal masih lemah untuk membuka peluang usaha dan peluang pekerjaan.

Peranan objek wisata ini dilihat dari banyaknya aktifitas-aktifitas ekonomi yang terjadi disekitar pantai seperti kegiatan dari bentuk usaha dagang ataupun pelayanan jasa seperti: 1) Warung Makan, 2) Penginapan, 3) Jajanan dan makanan, 4) Angkutan, 5) Dagang Kecil, 6) Ojek, 7) Usaha Kecil, 8) Usaha jasa pelampung, dan 9) Usaha jasa perahu. Dengan melihat diatas telah jelas bahwa peranan dari kegiatan ekonomi adalah adanya peningkatan pendapatan masyarakat atau variasi kegiatan ekonomi bertambah, pembukaan lapangan pekerjaan, dan pertumbuhan wilayah. Saat ini tengah dilakukan perbaikan sarana dan prasarana seperti penambahan tempat peristirahatan untuk pengunjung dan wisatawan yang datang agar pengunjung dapat menikmati keindahan Pantai Nambo dengan tenang dan tentram dan lokasi wisata tersebut dapat terpelihara dengan baik.

Sejauh ini belum diketahui seberapa besar peranan sektor pariwisata terhadap perekonomian di sekitar Kelurahan Pantai Nambo secara komprehensif. Berdasarkan latar belakang diatas, perlu dilakukan kajian untuk mendapatkan data dan informasi yang berguna. Penelitian ini berusaha mendiskripsikan manfaat dari. Untuk itu peneliti mengangkat judul "Dampak Wisata Pantai Nambo Terhadap Perekonomian Masyarakat Di Kelurahan Nambo Kecamatan Abeli Kota Kendari”.

\section{METODE PENELITIAN}

\section{Lokasi dan Waktu Penelitian}

Penelitian ini dilakukan di Kawasan Wisata Pantai Nambo Kelurahan Nambo Kecamatan Abeli Kota Kendari pada bulan April sampai dengan Mei 2018. Penentuan lokasi ini dilakukan secara sengaja (purposive). Alasan pemilihan Kelurahan Nambo sebagai lokasi kajian adalah sebagai berikut:

1. Di Kelurahan Nambo sebagai tempat wisata yang sangat potensial untuk dikembangkan.

2. Dalam perkembangannya Wisata Pantai Nambo ini menjadi unggulan bagi Kelurahan Nambo pada khususnya maupun Kabupaten/Kota pada umumnya.

3. Keadaan lingkungan Wisata Pantai Nambo saat ini dijadikan sebagai 
lokasi wisata pantai dan sebagai sumber pencaharian kehidupan masyarakat setempat utamanya menengah kebawah, sehingga perlu dikaji untuk dikembangkan.

\section{Jenis dan Sumber Data}

Jenis dan sumber data pada penelitian ini adalah menggunakan data primer. Data primer adalah data yang di peroleh langsung dari lokasi penelitian yang bertempat di Kawasan Wisata Pantai Nambo. Data diambil menggunakan metode wawancara berdasarkan panduan pertanyaan dengan menggunakan kuisioner jumlah jenis usaha pariwisata.

\section{Faktor yang Diteliti}

Faktor yang diselidiki dalam penelitian ini adalah peranan objek wisata Nambo terhadap perekonomian masyarakat di sekitar Kelurahan Nambo Kota Kendari berdasarkan jenis bidang usaha pariwisata.

\section{Populasi dan Sampel}

Populasi dan sampel dalam penelitian ini adalah semua masyarakat dengan ketentuan yang mempunyai usaha di sekitar daerah objek wisata, yang diambil adalah kepala keluarga dengan metode quota random sampling yaitu yang terlibat dengan kegiatan di pantai Nambo. Sampel yang diambil adalah yang memiliki usaha di sekitar masing-masing usaha di objek wisata.

\section{Teknik Pengumpulan Data}

Teknik pengumpulan data dilakukan dalam bentuk penelitian lapangan field research) yakni mengadakan penelitian langsung dengan tekknik : a. Teknik wawancara, yaitu teknik pengumpulan data dengan cara tanya jawab dengan responden. b. Teknik kepustakaan adalah teknik pengumpulan data yang telah didokumentasikan oleh pemerintah dan intansi yang ada hubungannya dengan penelitian. Pengumpulan data dilakukan dengan menyebarkan kuisioner serta wawancara langsung dengan responden untuk menjawab sejumlah pertanyaan yang diajukan.

\section{Teknik Analisis Data}

Teknik analisis data dilakukan dengan menggunakan analisis deskriptif kualitatif. Analisis ini untuk mendeskripsikan, menggambarkan, menjabarkan, atau menguraikan data (Ramli, 2009). Analisisnya adalah membandingkan secara deskriptif keadaan responden sebelum dan sesudah pengembangan obyek wisata. Perbandingan keadaan responden ini diukur dengan melakukan perhitungan dari presentase aktivitas ekonomi dan pendapatan sebelum dan sesudah ada objek wisata. Adapun cara menentukan presentase sebelum dan sesudah adanya objek wisata dapat dilihat sebagai berikut.

\section{Defenisi Operasional}

Untuk menghindari penafsiran yang salah, maka perlu dijelaskan beberapa pengertian sebagai berikut:

1. Pariwisata adalah kegiatan dari saling hubungan antara perjalanan (travelling) dan menginap dari yang bukan penduduk (stay non residence) dalam rangka melakukan aktifitas waktu luang atau dalam konteks bisnis dan study.

2. Peranan objek wisata adalah keterkaitan antara tempat wisata dengan ekonomi yang sangat erat dengan banyak sektor.

\section{HASIL PENELITIAN}

Berdasarkan temuan data di lokasi penelitian Pantai Nambo Kota Kendari yang terpilih dalam penelitian ini ternyata ada 19 kepala keluarga sebagai responden 
dari jenis usaha yang berhubungan erat dengan objek wisata. Penelitian ini mengambil responden yang memiliki usaha di sekitar objek wisat tersebut. Bidang usaha tersebut terdiri dari kios, gazebo, penyewaan ban, tikar, penyewaan
WC, air bilas, warung makan dan penginapan. Untuk masing-masing usaha membandingkan keadaan responden sebelum dan sesudah pengembangan objek wisata.

Tabel 3.1. Rekapitulasi hasil wawancara peneliti pada objek wisata pantai Nambo.

\begin{tabular}{|c|c|c|c|}
\hline \multirow{2}{*}{ No } & \multirow{2}{*}{ Pertanyaan } & \multicolumn{2}{|c|}{ Jumlah Responden } \\
\hline & & Orang (KK) & $(\%)$ \\
\hline \multirow{7}{*}{1.} & $\begin{array}{l}\text { Apakah pekerjaan pokok Bapak/Ibu sebelum } \\
\text { adanya Objek wisata Pantai Nambo? }\end{array}$ & & \\
\hline & a. Pedagang & 4 & 21,05 \\
\hline & b. PNS & 2 & 10,53 \\
\hline & c. Tukang ojek, kayu dan batu & 3 & 15,79 \\
\hline & d. Penjual & 1 & 5,26 \\
\hline & e. Nelayan & 7 & 36,84 \\
\hline & f. Petani & 2 & 10,53 \\
\hline
\end{tabular}

Berapakah pendapatan dari pekerjaan pokok yang diperoleh sebelum membuka usaha pada objek wisata pantai Nambo ?

2. a. $350.000-400.000$

b. $500.000-600.000$ 31,58

c. $700.000-1.000 .000$

d. $>1.000 .000$

Setelah adanya objek wisata pantai Nambo pekerjaan tambahan apa saja yang Bapak/Ibu geluti ?

\begin{tabular}{lcc}
\hline a. Penyewaan Tikar+Gazebo & 4 & 21,05 \\
\hline b. Penginapan & 2 & 10,53 \\
\hline c. Penjaga WC & 1 & 5,26 \\
\hline d. Kios & 4 & 21,05 \\
\hline e. WarungMakan+ruang bilas & 2 & 10,53 \\
\hline f. Makanan+minimuan saji & 2 & 10,53 \\
\hline $\begin{array}{l}\text { g. Penyewaan gazebo+ruang bilas + penyewaan } \\
\text { ban }\end{array}$ & 4 & 21,05 \\
\hline
\end{tabular}

Pendapatan tambahan setelah adanya objek wisata pantai Nambo ?

4. a. $350.000-400.000$

b. $500.000-600.000$

c. $700.000-1.000 .000$

21,05

d. $>1.000 .000$

$\begin{array}{ll}4 & 21,05 \\ 4 & 21,05\end{array}$

Keberadaan objek wisata ini memberikan peluang kepada Bapak/Ibu untuk membuka lapangan

5. usaha?
a. Ya
19
100
b. Tidak
- $\quad-$ 
Jurnal Penelitian Pendidikan Geografi Volume 4 No.1 Januari 2019

\begin{tabular}{|c|c|c|c|}
\hline \multirow{2}{*}{ No } & \multirow{2}{*}{ Pertanyaan } & \multicolumn{2}{|c|}{ Jumlah Responden } \\
\hline & & Orang (KK) & $(\%)$ \\
\hline \multirow[t]{4}{*}{6.} & $\begin{array}{l}\text { Penghasilan yang Bapak/Ibu terima saat saat ini } \\
\text { cukup untuk memenuhi kebutuhan sehari-hari ? }\end{array}$ & & \\
\hline & a. $\mathrm{Ya}$ & 14 & 73,68 \\
\hline & b. Tidak & 5 & 26,32 \\
\hline & $\begin{array}{l}\text { apakah objek wisata nambo berperan dalam } \\
\text { meningkatkan pendapatan masyarakat? }\end{array}$ & & \\
\hline \multirow[t]{4}{*}{7.} & a. Tidak Berperan & - & - \\
\hline & b. Kurang Berperan & - & - \\
\hline & c. Cukup Berperan & 7 & 36,84 \\
\hline & d. Sangat Berperan & 12 & 63,16 \\
\hline \multirow{5}{*}{8.} & $\begin{array}{l}\text { Apakah penting ada pengelola limba di kawasan } \\
\text { pantai nambo? }\end{array}$ & & \\
\hline & a. $\quad$ Tidak Penting & - & - \\
\hline & b. Kurang Penting & - & - \\
\hline & c. Cukup Penting & - & - \\
\hline & d. Penting & 19 & 100 \\
\hline \multirow{5}{*}{9.} & $\begin{array}{l}\text { Menurut Bapak/Ibu, tindakan apa sajakah yang } \\
\text { perlu dilakukan oleh pemerintah agar keberadaan } \\
\text { objek wisata ini lebih memberikan dampak } \\
\text { positif bagi ekonomi masyarakat? }\end{array}$ & & \\
\hline & $\begin{array}{l}\text { Memberikan denda kepada masyarakat yang } \\
\text { mengotori objek wisata }\end{array}$ & 5 & 26,32 \\
\hline & $\begin{array}{l}\text { benurunkan pajak daerah kepada pelaku } \\
\text { usaha }\end{array}$ & 6 & 31,58 \\
\hline & $\begin{array}{ll}\text { c. Dibangunkan tempat usaha agar terlihat } \\
\text { seragam }\end{array}$ & 5 & 26,31 \\
\hline & $\begin{array}{l}\text { d. Lebih mengeksplor objek wisata pantai } \\
\text { Nambo agar mendapatkan pengunjung yang } \\
\text { lebih banyak lagi }\end{array}$ & 3 & 15,79 \\
\hline
\end{tabular}

Sumber data Primer 2018

Dari tabel terdapat jawaban responden dari kuisioner yang telah dijawab sebagai berikut:

1. Apakah pekerjaan pokok Bapak/Ibu sebelum adanya Objek wisata Pantai Nambo ?

Dari hasil jawaban responden pencaharian nelayan terdapat 7 kepala keluarga (KK), menyusul responden yang memiliki aktivitas ekonomi sebagai pedagang sebanyak 4 kepala keluarga (KK), tukang ojek/kayu/batu sebanyak 3 kepala keluarga (KK), aktifitas ekonomi sebagai PNS sebanyak 2 kepala keluarga (KK), petani 2 kepala keluarga $(\mathrm{KK})$ dan 1 kepala keluarga petani (KK).

2. Berapakah pendapatan dari pekerjaan pokok yang diperoleh sebelum membuka usaha pada objek wisata pantai Nambo ?

Terdapat 15 kepala keluarga (KK) yang memiliki pendapatan rendah dan 4 kepala keluarga (KK) yang berpendapatan menengah. 
3. Setelah adanya objek wisata pantai Nambo pekerjaan tambahan apa saja yang dibuatkan usaha?

Terdapat pekerjaan tambahan penyewaan tikar+gazebo 4 kepala keluarga $(\mathrm{KK})$, penginapan 2 kepala keluarga (KK), penjaga WC 1 kepala keluarga (KK), Kios 4 kepala keluarga (KK), Warung Makan+ruang bilas terdapat 2 kepala klelaurga (KK), Makanan+minimuan saji terdapat 2 kepala klelaurga (KK) dan Penyewaan gazebo+ruang bilas + penyewaan ban terdapat 4 kepala keluarga (KK).

4. Berapakah pendapatan ta mbahan setelah adanya objek wisata pantai Nambo ?

Terdapat 6 kepala keluarga (KK) yang memiliki pendapatan 700.000 - 1.000.000 dan 13 kepala keluarga (KK) memiliki pendapatan di atas Rp 1.000.000.

5. Apakah keberadaan objek wisata ini memberikan peluang kepada Bapak/Ibu untuk membuka lapangan usaha?

Semua responden menjawab (ya).

6. Apakah penghasilan yang bapak/ibu terima saat ini cukup untuk memenuhi kebutuhan sehari-hari ?

14 kepala keluarga (KK) menjawab respon (ya) dan 5 kepala keluarga (KK) menjawab (tidak).

7. apakah objek wisata nambo berperan dalam meningkatkan pendapatan masyarakat?

Terdapat 7 kepala keluarga (KK) yang menjawab (cukup berperan) dan 12 kepala keluarga (KK) menjawab (sangat berperan).
8. Apakah penting ada pengelola limba di kawasan pantai nambo?

Semua responden menjawab sangat penting.

9. Menurut bapak/ibu, tindakan apa sajakah yang perlu dilakukan oleh pemerintah agar keberadaan objek wisata ini lebih memberikan dampak positif bagi ekonomi masyarakat?

Terdapat 5 kepala keluarga (KK) yang menjawab (memberikan denda kepada masyarakat yang mengotori objek wisata, 6 kepala keluarga (KK) yang menjawab (menurunkan pajak daerah kepada pelaku usaha), 5 kepala keluarga (KK) yang menjawab (dibangunkan tempat usaha agar terlihat seragam) dan 3 kepala keluarga (KK) yang menjawab (lebih mengeksplor objek wisata pantai Nambo agar mendapatkan pengunjung yang lebih banyak lagi).

Kondisi Perekonomian Responden Di Kelurahan Toronipa Sebelum Adanya Obyek Wisata Pantai

\section{Aktivitas Ekonomi Responden}

Sumber penghidupan masyarakat di Kelurahan Nambo Kecamatan Abeli sebelum pengembangan obyak wisata pantai pada umumnya adalah nelayan. Sektor perikanan dan kelautan jenis komoditi yang diusahakan berupa ikan dan kepiting, sementara dari sektor pertanian jenis komoditi yang dihasilkan adalah singkong.

Untuk mengetahui jenis pekerjaan pokok responden Kelurahan Nambo Kecamatan Abeli sebelum adanya obyek wisata pantai, penulis sajikan pada Tabel 3.2 berikut: 
Tabel 3.2. Rata-Rata Pendapatan Responden Sebelum adanya Obyek Wisata Pantai, Tahun 2018

\begin{tabular}{lccc}
\hline No. & Pekerjaan Pokok & Responden (KK) & Persentase (\%) \\
\hline 1 & Pedagang & 4 & 21,05 \\
\hline 2 & PNS & 2 & 10,53 \\
\hline 3 & $\begin{array}{c}\text { Tukang Ojek, } \\
\text { Kayu dan Batu }\end{array}$ & 3 & 15,79 \\
\hline 4 & Penjual & 1 & 5,26 \\
\hline 5 & Nelayan & 7 & 36,84 \\
\hline 6 & Petani & 2 & 10,53 \\
\hline & Jumlah & $\mathbf{1 9}$ & $\mathbf{1 0 0}$
\end{tabular}

Sumber data Primer 2018

Pada Tabel 3.2 nampak bahwa sebagian besar responden bergerak di perikanan dan kelautan (nelayan) yakni sebanyak 7 kepala keluarga atau 36,84 persen, menyusul responden yang memiliki pekerjaan pokok sebagai pedagang sebanyak 4 kepala keluarga atau 21,05 persen, selanjutnya yang memiliki pekerjaan pokok sebagai tukang ojek/kayu/batu sebanyak 3 kepala keluarga atau 15,79 persen, yang memiliki pekerjaan pokok sebagai PNS sebanyak 2 kepala keluarga atau 10,53 persen, yang memiliki pekerjaan pokok sebagai petani 2 kepala keluarga atau 10,53 persen dan terakhir yang memiliki pekerjaan pokok sebagai petani sebanyak 1 kepala keluarga atau 5,26 persen.

Jadi dapat disimpulkan bahwa kehidupan perekonomian responden dilihat dari pekerjaan pokoknya masih relatif kurang baik. Sebab untuk menjadi nelayan hasil yang diperoleh masih bekum begitu optimal. Karena para nelayan masih kekurangan sarana penangkapan ikan dan kepiting masih banyak nelayan yang menggunakan alat tangkap tradisional yang tentu saja pendapatan mereka hanya mampu untuk memenuhi kebutuhan sendiri, disamping itu untuk melakukan penangkapan ikan dan kepiting tergantung musim.

\section{Pendapatan Responden}

Pendapatan merupakan nilai bersih penerimaan yang diperoleh responden dari hasil usaha yang dilakukan baik sebagai petani, nelayan, pedagang maupun lainnya. Hasil penelitian menunjukkan bahwa sebelum adanya pengembangan obyek wisata pantai, pendapatan yang diperoleh responden masih tergolong rendah, untuk lebih jelasnya ditampilkan pada Tabel 3.3 berikut:

Tabel 3.3. Rata-Rata Pendapatan Responden Sebelum adanya Obyek Wisata Pantai, Tahun 2018

\begin{tabular}{lllcc}
\hline No & $\begin{array}{l}\text { Pendapatan } \\
(\mathbf{R p} / \text { bulan })\end{array}$ & \multicolumn{1}{c}{ Aktifitas Ekonomi } & $\begin{array}{c}\text { Responden } \\
(\text { KK) }\end{array}$ & $\begin{array}{c}\text { Presentase } \\
(\mathbf{\%})\end{array}$ \\
\hline 1 & $\begin{array}{l}350.000- \\
400.000\end{array}$ & $\begin{array}{l}\text { Pedagang + Tukang } \\
\text { Ojek + Nelayan (4) }\end{array}$ & 6 & 31,58 \\
\hline 2 & $\begin{array}{l}500.000- \\
600.000\end{array}$ & $\begin{array}{l}\text { Penjual + Petani + } \\
\text { Pedagang + Nelayan (2) }\end{array}$ & 5 & 26,32 \\
\hline 3 & $700.000-$ & Petani + Tukang & 4 & 21,05 \\
\hline
\end{tabular}




\begin{tabular}{|c|c|c|c|c|}
\hline No & $\begin{array}{c}\text { Pendapatan } \\
\text { (Rp/bulan) }\end{array}$ & Aktifitas Ekonomi & $\begin{array}{l}\text { Responden } \\
\text { (KK) }\end{array}$ & $\begin{array}{c}\text { Presentase } \\
(\%)\end{array}$ \\
\hline & 1.000 .000 & $\begin{array}{l}\text { Kayu/Batu + Pedagang + } \\
\text { Nelayan }\end{array}$ & & \\
\hline 4 & $>1.000 .000$ & $\begin{array}{l}\text { PNS (2) + Tukang } \\
\text { Kayu/Batu + Pedagang }\end{array}$ & 4 & 21,05 \\
\hline \multicolumn{3}{|c|}{ Jumlah } & 19 & $100 \%$ \\
\hline
\end{tabular}

Sumber: Data Primer (diolah) 2018

Tabel 3.3 menunjukkan bahwa sebagian besar responden masih tergolong pendapatan rendah yaitu sejumlah 6 kepala keluarga atau 31,58 persen, berpendapatan sebesar Rp. 350.000 400.000,-/bulan. Sedangkan responden yang mempunyai pendapatan Rp. > 1.000.000,-/bulan sebanyak 4 kepala keluarga atau 21,05 persen.

Bila melihat data-data di atas kondisi perekonomian reponden pada umumnya bermata pencaharian sebagai nelayan tradisional dan tingkat ketergantungan pada alam yang sangat tinggi menyebabkan aktivitas, dimana waktu lebih banyak terbuang percuma sehingga perubahan ekonomi terkesan begitu lambat. Umumnya masyarakat di Kelurahan Nambo masih berpendapatan rendah ini disebabkan mata pencaharian mereka hanya tergantung pada keadaan alam seperti kegiatan lain untuk menambah pendapatan tidak ada.

Jadi kesimpulannya mereka belum memiliki pekerjaan sampingan yang dapat mendukung pekerjaan pokoknya. Uraian di atas memberikan gambaran kepada kita bahwa obyek wisata pantai sebelum dikembangkan menjadi obyek wisata, pendapatan masyarakat masih rendah dan belum dapat memberikan keuntungan yang lebih baik.

\section{Kondisi Perekonomian Responden Di Kelurahan Toronipa Sesudah Adanya Pengembangan Obyek Wisata Pantai \\ 1. Aktivitas Ekonomi Responden}

Adanya kegiatan kepariwisataan sudah dapat dipastikan akan membuka lapangan kerja dan lapangan usaha, baik langsung maupun tidak langsung, misalnya di bidang prasarana dan sarana yang berarti memberi peluang kepada pekerjaan untuk dapat menghasilkan uang dari pekerjaan tersebut.

Banyaknya wisatawan yang berkunjung ke Kelurahan Nambo ini,khusunya di pantai Nambo dapat memperbaiki keadaan perekonomian masyarakat, dimana pada saat sebelum pengembangan kawasan wisata pantai masyarakat banyak yang bekerja sebagai nelayan,petani dan ada pula yang merantau keluar daerah untuk mencari pekerjaan,namun sesudah adanya pengembangan obyek wisata pantai masyarakat yang tadinya merantau banyak yang kembali untuk beraktivitas di sektor pariwisata.

Berdasarkan hasil wawancara dengan warga setempat mereka bekerja sebagai pedagang dan penyedia jasa dan lain-lain yang semuanya itu untuk memenuhi kebutuhan para wisatawan.Adanya sumber mata pencaharian itu tentu akan membuat mereka betah tinggal di kampong halaman serta dengan meningkatnya kunjungan wisatawan dapat merubah keadaan perekonomian responden ke arah yang lebih baik dibanding sebelum adanya pengembangan obyek wisata.

Berdasarkan hasil penelitian jenis pekerjaan tambahan responden sesudah adanya obyek wisata pantai yang bergerak di sektor pelayanan jasa kepariwisataan dimana responden telah mendapatkan pekerjaan tambahan yang akan menambah aktivitas responden kearah yang lebih baik dan akan menambah pendapatan yang lebih besar dibandingkan dengan sebelum 
adanya pengembangan wisata pantai. Untuk lebih jelasnya pekerjaan tambahan yang dilakukan oleh responden dalam penelitian ini dapat dilihat pada Tabel 3.4 berikut:

Tabel 3.4. Jenis Pekerjaan Tambahan Responden Sesudah Adanya Obyek Wisata Pantai, Tahun 2018

\begin{tabular}{|c|c|c|c|c|}
\hline No & $\begin{array}{c}\text { Aktifitas } \\
\text { Sebelumnya }\end{array}$ & $\begin{array}{c}\text { Aktifitas } \\
\text { Tambahan }\end{array}$ & $\begin{array}{c}\text { Responden } \\
\text { (KK) }\end{array}$ & $\begin{array}{c}\text { Persentase } \\
(\%)\end{array}$ \\
\hline 1 & $\begin{array}{l}\text { Pedagang }+ \\
\text { Tukang kayu }+ \\
\text { Nelayan (2) }\end{array}$ & $\begin{array}{l}\text { Penyewaan } \\
\text { Tikar + } \\
\text { Gazebo }\end{array}$ & 4 & 21,05 \\
\hline 2 & PNS (2) & Penginapan & 2 & 10,53 \\
\hline 3 & Tukang Ojek & Penjaga WC & 1 & 5,26 \\
\hline 4 & $\begin{array}{l}\text { Penjual + } \\
\text { Nelayan }(2)+ \\
\text { Pedagang }\end{array}$ & Kios & 4 & 21,05 \\
\hline 5 & $\begin{array}{l}\text { Petani + } \\
\text { Pedagang }\end{array}$ & $\begin{array}{l}\text { Warung } \\
\text { Makan + } \\
\text { ruang bilas }\end{array}$ & 2 & 10,53 \\
\hline 6 & Nelayan (2) & $\begin{array}{l}\text { Makanan + } \\
\text { minimuan } \\
\text { saji }\end{array}$ & 2 & 10,53 \\
\hline 7 & $\begin{array}{l}\text { Tukang } \\
\text { Kayu/Batu + } \\
\text { Petani + } \\
\text { Pedagang + } \\
\text { Nelayan }\end{array}$ & $\begin{array}{l}\text { Penyewaan } \\
\text { gazebo }+ \\
\text { ruang bilas }\end{array}$ & 4 & 21,05 \\
\hline \multicolumn{3}{|c|}{ Jumlah } & 19 & $100 \%$ \\
\hline
\end{tabular}

Sumber: Data Primer (diolah), 2018

Pada Tabel 3.4 menunjukkan bahwa jenis aktivitas ekonomi sesudah adanya pengembangan obyek wisata pantai menunjukkan jenis aktivitas tambahan responden yaitu penginapan sebanyak 2 kepala keluarga atau 10,53 persen, penjaga WC sebanyak 1 kepala keluarga atau 5,26 persen, kegiatan ekonomi tambahan kios sebanyak 4 kepala keluarga atau 21,05 persen, selanjutnya aktifitas ekonomi warung makan/ruang bilas sebanyak 2kepala keluarga atau 10,53 persen, penjual makanan dan minumun saji sebanyak 2 kepala keluarga atau 10,53 persen, sedangkan aktifitas ekonomi seperti penyewaan gazebo/ruang bilas/penyewaan ban sebanyak 4 kepala keluarga atau 21,05 persen. Dimana yang sebelumnya aktivitas responden hanya sebagai nelayan, petani, tukang kayu/batu/ojek, penjual, pedagang dan PNS akan tetapi dengan adanya pengembangan obyek wisata pantai ternyata seluruh responden mendapat pekerjaan sampingan dalam bidang pariwisata.

Beberapa tarif fasilitas di obyek wisata pantai yang disiapkan oleh masyarakat untuk wisatawan dapat dilihat pada Tabel 3.5 berikut: 
Jurnal Penelitian Pendidikan Geografi Volume 4 No.1 Januari 2019

Tabel 3.5. Jenis Usaha dan Tarif di Obyek Wisata Pantai, Tahun 2018

\begin{tabular}{clc}
\hline No. & Jenis Usaha & Tarif $(\mathbf{R p )}$ \\
\hline 1 & Penyewaan Tikar & 15.000 \\
\hline 2 & Penyewaan Gazebo & 100.000 \\
\hline 3 & Penginapan & 200.000 \\
\hline 4 & Penyewaan WC & 10.000 \\
\hline 5 & Ruang Bilas & 2.500 \\
\hline 6 & Makanan dan minuman saji & 23.000 \\
\hline 7 & Penyewaan Ban & 5.000 dan 10.000 \\
\hline
\end{tabular}

Sumber: Data Primer, 2018

Tabel 3.5 menunjukkan berbagai jenis usaha dan tarifnya yang ada di obyek wisata pantai. Jenis usaha tersebut merupakan bisnis yang sangat berkembang dan memberikan dampak terhadap peningkatan pendapatan masyarakat. Jenis usaha tersebut antara lain gazebo, ban pelampung, ruang bilas,sewa tikar, sewa WC dan penginapan. Gazebo berfungsi sebagai tempat istrahat bagi pengunjung yang ingin bersantai menikmati pemandangan pantai. Tarif gazebo untuk sekali pakai adalah Rp. 100.000 dengan tidak membatasi jumlah penyewa. Ada juga pengunjung yang tidak memesan gazebo melainkan tikar aja untuk tempat istirahat mereka. Tariff yang dipakai untuk penyewaan tikar adalah Rp. 15.000.

Fasilitas renang yang disewakan di pantai adalah ban pelampung. Ban pelampung terdiri dari berbagai ukuran dengan tarif sekali pakai untuk ukuran kecil dan sedang adalah Rp. 5.000 serta ukuran paling besar Rp. 10.000. Setelah melakukan aktifitas renang dipantai biasanya pengunjung melakukan pembersihan diri dengan air tawar. Adapun fasilitas yang dapat disewakan adalah ruang bilas dan WC. Ruang bilas digunakan pengunjung untuk membersihkan diri dang anti pakaian dengan tarif untuk sekali pakai adalah $\mathrm{Rp}$. 2.500. sedangkan untuk sewa WC Rp. 10.000untuk pemakaian mandi, buang air kecil dan air besar.

Jenis usaha lain yang disewakan adalah penginapan untuk sewa penginapan per kamar dikenakan tarif Rp.150.000 selama 24 jam. Pantai ini pula memiliki makanan khas yaitu sate pokea dengan harga Rp. 1.000.00/tusuk, es kelapa Rp. 7.000.00/gelas, dan ikan bakar Rp.15.000.00 dalam 1 porsi, akan tetapi ikan bakar ini hanya tersedia pada hari libur seperti tahun baru dan libur hari besar.

\section{Pendapatan Responden}

$\begin{array}{ccc}\text { Pada bagian awal telah } \\ \text { dikemukakan } & \text { mengenai jumlah }\end{array}$ pendapatan yang diperoleh masyarakat sebelum pengembangan obyek wisata pantai Nambo. Sebagaimana halnya dengan ciri pariwisata pada umumnya yaitu memberikan efek yang positif bagi masyarakat di sekitar obyek wisata tersebut. Adanya obyek wisata maka masyarakat dapat memperoleh pekerjaan sampingan. Kondisi ini mengakibatkan masyarakat akan memperoleh tambahan pendapatan, demikian pula yang terjadi di Kelurahan Nambo dengan dikembangkannya obyek wisata pantai baik pendapatan masyarakat setempat maupun sarana dan prasarana di Kelurahan akan meningkat dan lebih baik.

Berdasarkan data yang diperoleh bahwa pendapatan responden umumnya di atas rata-rata dan mengalami peningkatan sesudah adanya pengembangan pariwisata pantai, hal ini disebabkan selain pendapatan pokok responden meningkat mereka juga mempunyai pendapatan lain dari pekerjaan sampingan yang lebih menguntungkan. Pekerjaan sampingan yang dimaksud seperti pedagang,penyedia 
pelampung ban serta masih banyak jasajasa lainnya yang dibutuhkan oleh para wisatawan. Untuk lebih jelasnya rata-rata jumlah pendapatan responden sesudah adanya pengembangan obyek wisata pantai, penulis sajikan pada Tabel 5.5 berikut:

Tabel 3.5. Rata-Rata Pendapatan Responden Sesudah Adanya Obyek Wisata Pantai, Tahun 2018

\begin{tabular}{|c|c|c|c|c|}
\hline No. & $\begin{array}{c}\text { Pendapatan } \\
\text { Rp/bulan }\end{array}$ & Aktifitas Tambahan & $\begin{array}{c}\text { Responden } \\
\text { (KK) }\end{array}$ & $\begin{array}{c}\text { Persentase } \\
(\%)\end{array}$ \\
\hline 1 & $\begin{array}{l}350.000- \\
400.000\end{array}$ & - & - & - \\
\hline 2 & $\begin{array}{l}500.000- \\
600.000 \\
\end{array}$ & - & - & - \\
\hline 3 & $\begin{array}{l}700.000- \\
1.000 .000\end{array}$ & $\begin{array}{l}\text { Sewa Tikar + Gazebo, } \\
\text { Penjaga WC, Kios, } \\
\text { Makanan + Minuman } \\
\text { Saji (2), Penyewaan } \\
\text { gazebo + ruang bilas + } \\
\text { penyewaan ban, }\end{array}$ & 6 & 31,58 \\
\hline 4 & $>1.000 .000$ & $\begin{array}{l}\text { Penginapan (2), Kios } \\
(3), \text { Warung makan + } \\
\text { ruang bilas }(2), \text { Sewa } \\
\text { gazebo + tikar }(3), \\
\text { Penyewaan gazebo + } \\
\text { ruang bilas }+ \\
\text { penyewaan ban }(3),\end{array}$ & 13 & 68,42 \\
\hline & & umlah & 19 & $100 \%$ \\
\hline
\end{tabular}

Sumber: Data Primer (diolah), 2018

Tabel 5.5 menunjukan bahwa ratarata pendapatan responden sesudah adanya pengembangan obyek wisata pantai meningkat yakni, sebanyak 13 kepala keluarga atau 68,42 persen memiliki pendapatan diatas Rp. >1.000.000,-/bulan, 6 kepala keluarga atau 31,58 persen memiliki pendapatan Rp. 700.000 $1.000 .000,-/$ bulan, sedangkan responden yang berpendapatan Rp. 350.000,- 400.000,- dan Rp. 500.000,- - 600.000,/bulan tidak ada sama sekali.

Pendapatan responden yang semakin meningkat tersebut maka pemenuhan kebutuhan responden (masyarakat) atau keluarganya semakin terpenuhi baik kebutuhan primer maupun sekunder, sehingga kesejahteraan masyarakat atau keluarga diasumsikan akan semakin baik dari sebelum adanya pengembangan obyek wisata pantai.

Adanya pengembangan wisata pantai maka dampak perekonomian terlihat dari aktivitas masyarakat menunjukkan suatu perubahan kearah yang lebih baik, dimana sebelum pengembangan obyek wisata pantai aktivitas responden sebagian besar adalah nelayan dan pedagang serta yang lainnya sebagai petani, tukang kayu/batu/ojek,penjual danPNS.Namun dengan adanya pengembangan obyek wisata pantai responden mendapatkan pekerjaan sampingan (tambahan) untuk menambah pendapatan. 


\section{Implikasi Penelitian Terhadap Kurikulum Pendidikan di Sekolah}

Geografi adalah ilmu yang mempelajari persamaan dan perbedaan fenomena dengan sudut pandang kewilayahan dan kelingkungan dalam konteks keruangan. Wisata adalah kegiatan perjalanan atau sebagian dari kegiatan tersebut yang di lakukan secara sukarela, serta bersifat sementara waktu untuk menikmati obyek atau daya tarik wisata. Pariwisata adalah segala sesuatu yang berhubungan dengan wisata. Begitu juga dengan peranan objek wisata dalam perekonomian masyarakat yaitu proses peningkatan kualitas hidup.

Dapat diketahui dari hasil penelitian ini mengkaji bahwa ternyata penentuan suatu lokasi yang dijadikan objek wisata dan dapat menambah/meningkatkan perokonomian pelaku usaha. Penelitian ini berkaitan dengan materi pelajaran SMA Kelas XI materi emanfaatan Sumber Daya Alam yang Dapat Diperbaharui submateri laut sebagai tempat objek wisata bahari.

Dalam peranan objek wisata terhadap perekonomian masyarakat sekitar yang melakukan usaha di lokasi kawasan obyek wisata Pantai Nambo Kecamatan Abeli Kota Kendari, kondisi geografi sekitar obyek wisata menjadi sangat penting dalam pelaksanaan pengembangan kawasaan obyek wisata agar siklus perokonomian masyarakat sekitar dapat meningkat dan pengembangan agar sesuai dengan tujuan yang ingin di capai.

Sehinnga Pendidikan Geografi yang mengampu menanteng Diknas yang berkaitan, perlu terjadi simbiosis dengan Jurusan Ilmu Sosial dan Ekonomi. Dengan adanya hal tersebut maka dalam kedepanya peningkatan perekonomian pelaku usaha disekitar objek wisata akan lebih berkualitas. Dengan tersinkronisasinya hal diatas maka akan terwujudnya suatu tatanan masyarakat yang sejahtera.

Dari penelitian ini dapat memberikan sumbangan bagi pengembangan Ilmu Geografi, khususnya penegembanngan geografi kepariwisataan dan sebagai bahan masukan bagi pemerintah (Dinas Pariwisata) untuk menentukan kebijakan-kebijakan dalam bidang pariwisata.

\section{KESIMPULAN}

Berdasarkan hasil penelitian dan pembahasan mengenai dampak pengembangan wisata bahari pantai Nambo terhadap perekonomia masyarakat di Kelurahan Nambo Kecamatan Abeli Kota Kendari dapat disimpulkan sebagai berikut:

1. Pengembangan obyek wisata pantai Nambo memberikan dampak positif terhadap aktivitas perekonomian masyarakat. Sebelum pengembangan wisata pantai Nambo, sebagian besar masyarakat bekerja sebagai petani dan nelayan, namun sesudah pengembangan obyek wisata pantai aktivitas ekonomi meningkat. Masyarakat mendapat pekerjaan tambahan sebagai pedagang makanan dan minuman serta penyedia jasa berupa fasilitas yang di sewakan untuk wisatawan seperti gazebo, penyewaan tikar, ruang bilas, ban pelampung, banana boat dan penginapan.

2. Pengembangan obyek wisata pantai juga berdampak pada pendapatan masyarakat, dimana sebelum pengembangan obyek wisata pantai tingkat pendapatan responden masih tergolong rendah yaitu sebanyak 4 kepala keluarga atau 21,05 persen berpendapatan Rp. > 1.000.000,/bulan. Sesudah adanya pengembangan obyek wisata pantai pendapatan responden mengalami peningkatan yakni sebanyak 13 kepala keluarga atau 68,42 persen memiliki pendapatan Rp. > 1.000.000,-/bulan. 


\section{DAFTAR PUSTAKA}

Abbas. R. 2002. Prospek Penerapan Ekoturisme Pada Taman Nasional Gunung. Yogyakarta:Graha Ilmu

Dahuri. R, Jacub. R, Ginting. S.P dan Sitepu, M.J, 1996. Pengelolaan Sumber daya Wilayah Pesisir dan Lautan Secara Terpadu. Penerbit PT. Pradnya Paramita. Jakarta.

D, Samsuridjal dan Kaelany HD. 1997.Peluang Di Bidang Pariwisata. Jakarta. Mutiara Sumber Widya.

Fandeli, C.H., 2004. Dasar-dasar Manajemen Kepariwisataan Alam, Liberty Yogyakarta.

Hartono, Hari, 1996. Perkembangan Pariwisata, Kesempatan Kerja dan Permasalahannya, Prisma:yogyakarta

Hartanto, 2001. Menjelang Pembangunan Pariwisata Yang Berkelanjutan : Prespektif Perencanaan Kebijaksanaan. Institut Teknologi Bandung. Bandung.

Linberg dan Hawkins. 1995. Ekoturisme: Jakarta: Sinar Grafika

Pitana, I Gede dan Gayatri, Putu G., 2005, Sosiologi Pariwisata, Yogyakarta :CV. Andi Offset.

Rahman, 2006. Perencanaan dan Pengembangan Pariwisata. PT. Pradnya Paramita. Jakarta.

Spillane, James J. 2001. Ekonomi Pariisata (Sejarah dan Prospeknya). Cetakan Ke -13. Yogyakarta: Kanisius.
Soekadijo, R. G.2001 Anatomi Pariwisata. PT Gramedia Pustaka Utama, Jakarta.

Suwantoro, 2004. Ekologi, Lingkungan Hidup dan Pembangunan. Djambatan, Jakarta.

Todaro, M.P., 1985. Ilmu Ekonomi Bagi Negara-Negara Sedang Berkembang, Buku I, Akademika Presindo, Jakarta.

Yuanke, 2003. Kajian Pengembangan ekowisata mangrove dan partisipasi masyarakat di Kawasan Lembonga, Bali. Pascasarjana IPB. Bogor. 